\title{
Analisis Prestasi Belajar Matematika : Dampak Model Pembelajaran Kooperatif Tipe Think-Pair-Square Ditinjau dari Aktivitas Belajar
}

\author{
Suriati \\ SMP Negeri 24, Jalan Prof.Dr.Hamka, Sukarame, Bandar Lampung 35133, Indonesia. \\ * Corresponding Author. E-mail: suryati.hartoyo@gmail.com
}

\begin{abstract}
Abstrak
Penelitian ini bertujuan adalah untuk mendeskripsikan efektivitas TPS (Think-PairSquare) ditinjau dari aktivitas belajar matematika dan efektivitas TPS ditinjau dari prestasi belajar matematika. Metode dalam penelitian ini adalah quasi eksperimen. Populasi penelitian adalah peserta didik kelas IX SMP Negeri 24 Bandar Lampung Tahun Ajaran 2017/2018. Sampel diperoleh dengan tehnik acak kelas dan terpilih kelas IX D sebagai kelas kontrol serta kelas IX E sebagai kelas eksperimen. Instrumen penelitian yang digunakan adalah tes prestasi belajar peserta didik yang berupa pre-test dan post-test, angket aktivitas belajar dan lembar observasi aktivitas belajar peserta didik. Hasil penelitian menunjukkan model pembelajaran TPS efektif ditinjau dari aktivitas belajar peserta didik dengan nilai $t_{\text {hitung }}=6,604>t_{\text {tabel }}=2,05553$ sehingga H0 ditolak. Selain itu, TPS juga efektif ditinjau dari prestasi belajar hasil analisis didapatkan bahwa nilai $\mathrm{p}$ adalah $0,000<\alpha$ sehingga $\mathrm{H} 0$ ditolak berarti ada perbedaan hasil pre-test dan posttest. Hal ini berarti bahwa model pembelajaran Think Pair Square (TPS) efektif ditinjau dari prestasi belajar.
\end{abstract}

Kata kunci: Kooperatif Tipe Think Pair Square, Aktivitas Belajar, Prestasi Belajar

\section{Abstract}

This study aims to describe the effectiveness of TPS (Think-Pair-Square) in terms of mathematical learning activities and the effectiveness of TPS in terms of learning achievement in mathematics. The method in this study was quasi-experimental. The study population was class IX students of SMP Negeri 24 Bandar Lampung Academic Year 2017/2018. The sample was obtained by random class technique and selected class IX D as the control class and class IX E as the experimental class. The research instrument used was a test of student achievement in the form of pre-test and post-test, learning activity questionnaire and observation sheet of learning activities of students. The results showed that the TPS learning model was effective in terms of the learning activities of students with a tcount $=6.604>t$ table $=2.05553$ so that $H O$ was rejected. In addition, TPS was also effective in terms of the learning achievement of the analysis results. It was found that the $p$ value was $0,000<\alpha$ so that $H 0$ was rejected, meaning there were differences in the results of the pre-test and post-test. This means that the Think Pair Square (TPS) learning model is effective in terms of learning achievement.

Keywords: Think Pair Square Cooperative, Learning Activities, Learning Achievement

\section{PENDAHULUAN}

Pendidikan adalah usaha sadar dan terencana untuk mewujudkan suasana belajar dan proses pembelajaran agar peserta didik secara aktif mengembangkan potensi dirinya untuk memiliki kekuatan spiritual keagamaan, pengendalian diri, kepribadian, kecerdasan, akhlak mulia, serta keterampilan yang diperlukan dirinya, masyarakat, bangsa dan Negara (Oktapiani, Wibawa, \& Garminah, 2016). Maka tenaga pendidik atau guru harus merencanakan secara rinci suatu pengajaran yang sesuai dengan tujuan yang telah ditetapkan. Salah satu masalah yang dihadapi dunia pendidikan kita adalah masalah lemahnya proses pembelajaran (Sanjaya, 2002). Oleh karena itu, guru 
harus memiliki strategi-strategi dalam menyampaikan suatu materi kepada peserta didik, sehingga proses pembelajaran akan berlangsung dengan baik.

Faktor yang menyebabkan sulitnya matematika bagi peserta didik adalah karena pembelajaran matematika di kelas kurang bermakna. Pada saat proses pembelajaran di kelas, guru langsung menyampaikan materi yang akan diajarkan. Hal ini dapat terlihat saat pembelajaran berlangsung, peserta didik cenderung berperilaku pasif.

Berdasarkan hasil belajar peserta didik kelas IX D SMPN 24 Bandar Lampung pada pembelajaran matematika materi statistika, dari 31 peserta didik yang mencapai standar ketuntasan belajar sebagaimana KKM yang ditetapkan sekolah yaitu 70 hanya 6 orang peserta didik yang tuntas atau $19,35 \%$.

Beberapa usaha telah dilakukan peneliti sebagai guru mata pelajaran matematika untuk meningkatkan hasil belajar peserta didik diantaranya peneliti telah berusaha melengkapi buku paket, mengulangi materi yang belum dimengerti.

Berdasarkan permasalahan yang dikemukakan tersebut maka penulis ingin melakukan perbaikan kualitas pembelajaran guna meningkatkan hasil belajar sekaligus melibatkan peserta didik menjadi aktif baik secara fisik, mental, intelektual, maupun emosional, mengembangkan kreatifitas dan menyenangkan. Salah satu upaya yang dilakukan untuk meningkatkan kualitas pembelajaran yaitu dengan menerapkan Model pembelajaran kooperatif tipe TPS (Think-Pair-Square).

Model pembelajaran kooperatif tipe Think Pair Square merupakan modifikasi dari model pembelajaran kooperatif tipe think pair share dan dikembangkan oleh Spencer Kangan pada Tahun 1933. Think Pair Square memberikan kesempatan kepada siswa mendiskusikan ide- ide mereka dan memberikan suatu pengertian bagi mereka untuk melihat cara lain dalam menyelesaikan masalah (Anwar \& Ugi, 2017).

Model pembelajaran kooperatif tipe TPS (Think-Pair-Square) sendiri adalah salah satu model pembelajaran yang menarik, karena Think Pair Square (TPS) merupakan salah satu model pembelajaran yang dikembangkan dari teori kontrukivisme yang merupakan perpaduan antara belajar secara mandiri dan belajar secara kelompok (Karyawati, Murda, \& Widiana, 2014).

Model ini mengandung tiga unsur penting yaitu Think (berpikir), Pair (berpasangan) dan Share (berbagi). (1)Thinking: pada tahap ini, guru mengajukan suatu pertanyaan atau masalah yang dikaitkan dengan pelajaran. Kemudian siswa diminta menggunakan waktu beberapa menit untuk berpikir sendiri mengenai jawaban tersebut. (2)Pairing: selanjutnya guru meminta kepada siswa untuk berpasangan dengan siswa lain dan mendiskusikan apa yang telah mereka pikirkan. Interaksi pada tahap ini diharapkan siswa dapat berbagi jawaban/ide yang telah mereka pikirkan sebelumnya. (3)Sharing: Pada langkah akhir ini, guru meminta pasanganpasangan tersebut untuk berbagi dengan keseluruhan kelas mengenai apa yang telah mereka diskusikan dengan pasangannya (Januartini, Agustini, \& Sindu, 2016).

Berdasarkan penelitian terdahulu, pengaruh model pembelajaran kooperatif tipe TPS (Think Pair Square) dapat meningkatkan hasil belajar (Agustin, Trisoni, \& Putra, 2018; Karyawati et al., 2014; Maznah, 2016; M. Siregar, n.d.; Solfitri \& Heleni, 2015; Sukmawati \& Nasrullah, 2017; Yaqin, Indriwati, \& Susilo, 2018), meningkatkan motivasi belajar 
(Januartini et al., 2016) serta untuk meningkatkan pemahaman konsep (Karubaba, Rahman, \& Arifin, 2019) dan berpikir kritis matematis (Sumaryati \& Sumarmo, 2013). Perbedaan dengan penelitian peneliti yaitu peneliti ingin mendeskripsikan efektifitas model pembelajaran kooperatif tipe TPS (Think Pair Square) ditinjau dari aktivitas dan prestasi belajar peserta didik.

Penelitian selanjutnya yaitu pengaruh beberapa macam model pembelajaran ditinjau dari aktivitas peserta didik (Azizah, 2013; Handhika, 2010; Ningtiyas \& Siswaya, 2012; Nugraheni \& Sugiman, 2013) dan prestasi belajar peserta didik (Amiluddin \& Sugiman, 2016; Deta, -, \& Widha, 2013; Fahrurrozi \& Mahmudi, 2014; Farhan \& Retnawati, 2014; Listyanto \& Munadi, 2013; Marlissa \& Widjajanti, 2015; Rusmawati, Candiasa, \& Kirna, 2013; Satriawan, 2017; N. C. Siregar \& Marsigit, 2015; Tiurma \& Retnawati, 2014; Wahidin \& Sugiman, 2014). Perbedaan dengan penelitian peneliti yaitu peneliti ingin mengetahui pengaruh model pembelajaran ditinjau dari aktivitas serta prestasi belajar peserta didik, model pembelajaran yang ingin diteliti peneliti yaitu model pembelajaran kooperatif tipe TPS (Think Pair Square) ditinjau dari aktivitas dan prestasi belajar peserta didik.

Berdasarkan penelitian terdahulu, belum pernah dilakukan penelitian untuk melihat pengaruh model pembelajaran kooperatif tipe TPS (Think Pair Square) ditinjau dari aktivitas dan prestasi belajar pada peserta didik, sehingga keterbaharuan peneliti adalah untuk mendeskripsikan efektivitas TPS (Think-Pair-Square) ditinjau dari aktivitas belajar matematika dan efektivitas TPS ditinjau dari prestasi belajar matematika pada peserta didik.

\section{METODE}

Metode yang diterapkan pada penelitian ini adalah metode Quasi eksperimen. Populasi penelitian ini adalah peserta didik kelas IX SMPN 24 Bandar Lampung. Sampel yang terpilih adalah kelas IX D dan IX E yang dipilih menggunakan tehnik acak kelas. Pemilihan subjek penelitian dilakukan dengan menyesuaikan antara karakteristik model pembelajaran kooperatif tipe TPS (Think-Pair-Square) dan karakteristik peserta didik.

Instrumen penelitian yang digunakan adalah tes prestasi belajar peserta didik yang berupa pre-test dan post-test, angket aktivitas belajar dan lembar observasi aktivitas belajar peserta didik.

Pengumpulan data pre test dan post test bertujuan untuk memperoleh data prestasi belajar peserta didik ssebelum dan sesudah diberi perlakuan pembelajaran menggunakan metode pembelajaran kooperatif tipe Think Pair Square (TPS). Pre test diberikan sebelum peserta didik mendapatkan perlakuan dan post test diberikan setelah peserta didik mendapatkan perlakuan. Metode kooperatif tipe Think Pair Square (TPS) akan dikatakan efektif apabila skor yang didapatkan dari hasil post test lebih dari atau sama dengan kriteria ketuntasan minimal, yaitu 75. Penyekoran hasil tes dilakukan untuk mendapatkan data dari hasil tes dengan nilai minimal 0 dan nilai maksimal 100.

Pengumpulan data non-tes meliputi data angket aktivitas peserta didik dan data observasi. Pengumpulan data dengan menggunakan instrumen angket aktivitas diisi sendiri oleh peserta didik untuk mengukur aktivitas peserta didik sebelum dan setelah dilaksanakan metode pembelajaran 
kooperatif tipe Think Pair Square (TPS). Skor minimal angket adalah 12 dan maksimal 48. Pemberian nilai pada hasil angket dilakukan dengan mengkonversikannya terlebih dahulu dalam rerata ideal dan simpangan baku. Konversi skor angket aktivitas belajar peserta didik ke dalam kategori dapat dilihat pada Tabel 1.

Tabel 1. Kategori Aktivitas Belajar Peserta Didik

\begin{tabular}{lll}
\hline No. & Interval Skor & Kategori \\
1 & $12 \leq \mathrm{X}<21$ & Rendah \\
2 & $21 \leq \mathrm{X}<30$ & Sedang \\
3 & $30 \leq \mathrm{X}<39$ & Tinggi \\
4 & $39 \leq \mathrm{X}<48$ & Sangat Tinggi \\
\hline
\end{tabular}

Keterangan :

$\mathrm{X}$ : Skor total

Deskripsi data dalam penelitian ini terbagi menjadi dua, yaitu deskripsi awal untuk menyelidiki rata-rata hitung (mean), ragam/varians, keberlakuan asumsi yaitu uji normalitas dan uji homogenitas varians, dan deskrispsi tahap akhir untuk menguji hipotesis. Uji hipotesis keefektifan model pembelajaran kooperatif Tipe Think Pair Square (TPS) Ditinjau dari Prestasi Belajar Matematika Hipotesis yang digunakan adalah sebagai berikut:

$$
\begin{aligned}
& \mathrm{H} 0: \mu 1 \leq 75 \\
& \mathrm{H} 1: \mu 1>75
\end{aligned}
$$

Taraf signifikansi yang digunakan $\alpha=0,05$ dan menggunakan uji t.

\section{HASIL DAN PEMBAHASAN}

Berikut deskripsi hasil angket aktivitas peserta didik antara kelas eksperimen dan kelas kontrol dapat dilihat pada Tabel 2.

Tabel 2. Skor Rata-rata, Standar Deviasi, Skor Maksimal dan Skor Minimal yang

\begin{tabular}{|c|c|c|c|c|}
\hline \multirow[t]{2}{*}{ Deskripsi } & \multicolumn{2}{|c|}{$\begin{array}{c}\text { Kelompok } \\
\text { Eksperimen }\end{array}$} & \multicolumn{2}{|c|}{$\begin{array}{c}\text { Kelompok } \\
\text { Kontrol }\end{array}$} \\
\hline & Awal & Akhir & Awal & Akhir \\
\hline Rata-rata & 25.7 & 35.5 & 29.7 & 30.1 \\
\hline Standar deviasi & 3.9 & 4.3 & 3.4 & 3.2 \\
\hline Skor maksimum yang diperoleh & 33 & 48 & 36 & 37 \\
\hline Skor maksimum angket & 48 & 48 & 48 & 48 \\
\hline Skor minimum yang diperoleh & 18 & 30 & 23 & 24 \\
\hline Skor minimum angket & 12 & 12 & 12 & 12 \\
\hline Banyak peserta didik & \multicolumn{2}{|c|}{27} & \multicolumn{2}{|c|}{22} \\
\hline
\end{tabular}
Mungkin pada Angket Aktivitas Kelas Kontrol dan Eksperimen

Berikut deskripsi hasil tes prestasi peserta didik antara kelas eksperimen dan kelas control dapat dilihat pada Tabel 3.

Tabel 3. Nilai Rata-rata, Standar Deviasi, Nilai Maksimal dan Nilai Minimal pada Pre test

\begin{tabular}{|c|c|c|c|c|}
\hline \multirow[t]{2}{*}{ Deskripsi } & \multicolumn{2}{|c|}{$\begin{array}{c}\text { Kelompok } \\
\text { eksperimen }\end{array}$} & \multicolumn{2}{|c|}{$\begin{array}{c}\text { Kelompok } \\
\text { kontrol }\end{array}$} \\
\hline & Awal & Akhir & Awal & Akhir \\
\hline Rata-rata & 56.8 & 99.11 & 47.4 & 78.9 \\
\hline Standar deviasi & 14.9 & 3.2 & 10.7 & 18.9 \\
\hline Nilai maksimum yang diperoleh & 100 & 100 & 60 & 94 \\
\hline Nilai maksimum yang mungkin & 100 & 100 & 100 & 100 \\
\hline Nilai minimum yang diperoleh & 20 & 84 & 30 & 10 \\
\hline Nilai minimum yang mungkin & 0 & 0 & 0 & 0 \\
\hline Banyak peserta didik & \multicolumn{2}{|c|}{27} & \multicolumn{2}{|c|}{22} \\
\hline
\end{tabular}
dan Post test Kelas Kontrol dan Eksperimen 
Berdasarkan deskripsi data kelas kontrol, skor awal aktivitas belajar dan skor akhir aktivitas belajar mengalami peningkatan rata-rata sebesar 0,32. Pada rata-rata nilai Pre-test dan Post-test juga mengalami peningkatan yang cukup signifikan yaitu sebesar 31,46. Deskripsi data skor awal aktivitas belajar dan skor akhir aktivitas belajar kelas eksperimen nampak bahwa setelah diberikan perlakuan berupa model pembelajaran kooperatif tipe TPS rata-rata aktivitas belajar peserta didik meningkat secara signifikan yaitu sebesar 9,82.

Berdasarkan nilai Pre-test dan Post-test pada kelas eksperimen, pada kelas ini rata-rata nilai juga mengalami peningkatan yang cukup signifikan yaitu sebesar 42,30. Hal ini sesuai dengan pendapat Johnson \& Johnson (Lie, 2004) bahwa suasana belajar cooperative learning dapat menghasilkan prestasi yang lebih tinggi, hubungan yang lebih positif, dan penyesuaian psikologis yang lebih baik.

Berdasarkan deskripsi data yang telah dilakukan diperoleh bahwa adanya peningkatan rata-rata skor aktivitas belajar dan nilai prestasi belajar peserta didik. Nampak bahwa peningkatan yang terjadi pada kelas eksperimen sangat signifikan. Hal ini disebabkan oleh banyak faktor, salah satunya karena adanya model pembelajaran yang berbeda antara kelas

eksperimen dan kelas kontrol.

Berdasarkan kelas eksperimen pembelajaran lebih bermakna dan menyenangkan bagi peserta didik. Lebih bermaknanya karena pada kelas eksperimen dengan menggunakan model pembelajaran kooperatif tipe Think Pair Square adalah sesuatu yang baru bagi peserta didik, karena selama ini model pembelajaran yang sering dipakai oleh guru adalah ekspositori. Lebih bermaknanya model pembelajaran kooperatif tipe Think Pair
Square karena pembelajaran lebih melibatkan peserta didik untuk menemukan sendiri konsep yang dipelajari bukan hanya terpaku pada penjelasan dari guru sehingga peserta didik dituntut aktif untuk mengikuti pembelajaran.

Hal ini nampak pada pembelajaran

Think Pair Square. Dalam kelas eksperimen, pembelajaran matematika dengan model pembelajaran kooperatif tipe Think Pair Square (TPS) menjadikan peserta didik lebih mampu mengembangkan aktivitas belajarnya khususnya oral activities, mental activities, dan emotional activities. Peserta didik mulai mau bertanya ketika ada yang tidak dipahami, mau mengeluarkan pendapat ketika tahap berpasangan dan berempat, mau berdiskusi dengan teman satu kelompok sehingga aktivitas belajar yaitu oral activites mulai berkembang. Kemudian dalam memecahkan masalah yang ada, menanggapi pendapat teman yang lain, serta mengambil keputusan dalam mencari penyelesaian permasalahan merupakan aktivitas belajar yaitu mental activities. Sedangkan ketika peserta didik terlihat gembira dan bersemangat saat mengikuti pembelajaran, berani mengungkapkan pendapat, serta terlihat tenang dalam menyampaikan pendapat merupakan peningkatan aktivitas belajar yaitu emotional activities.

Berdasarkan kelas kontrol, model pembelajaran yang digunakan adalah ekspositori. Model pembelajaran ini lebih cenderung menjadikan peserta didik menjadi kurang aktif karena dalam proses pembelajaran peran guru lebih dominan. Saat guru memberikan kesempatan peserta didik untuk bertanya, suasana kelaspun cenderung hening. Guru terkadang sudah memancing peserta didik dengan memberi pertanyaan-pertanyaan namun peserta didik tidak menanggapi 
atau lebih banyak diam. Ketika guru memberikan waktu kepada peserta didik untuk berdiskusi kelompok, banyak sekali peserta didik yang pasif dalam mengikuti diskusi dengan berbagai alasan. Uraian di atas sesuai dengan pendapat Sanjaya (2006) yakni pembelajaran ekspositori lebih banyak terjadi satu arah, maka kesempatan untuk mengontrol pemahaman peserta didik akan materi pembelajaran akan sangat terbatas pula, dan bisa mengakibatkan pengetahuan yang dimiliki peserta didik akan terbatas pada apa yang diberikan guru sehingga peserta didik cenderung tidak aktif dalam mengikuti pembelajaran serta pembelajaran terasa kurang bermakna.

Berdasarkan proses pembelajaran dengan model kooperatif tipe TPS menjadikan kegiatan pembelajaran menjadi lebih optimal, peserta didik menjadi aktif yakni melalui kegiatan diskusi dalam kelompok maupun saat presentasi.

\section{SIMPULAN DAN SARAN}

Berdasarkan hasil analisis dan pembahasan yang telah diperoleh, dapat disimpulkan bahwa model pembelajaran Kooperatif tipe Think Pair Square efektif ditinjau dari aktivitas belajar peserta didik dan prestasi belajar matematika.

Berdasarkan hasil penelitian dan beberapa temuan di lapangan, penulis menyarankan Lembaga pendidikan dapat menerapkan model pembelajaran Kooperatif tipe Think Pair Square dalam proses pembelajaran untuk meningkatkan aktivitas dan prestasi belajar peserta didik. Dan semoga apa yang diteliti dapat dilanjutkan lebih baik lagi dan lebih luas cakupannya dalam konsep materi oleh peneliti selanjutnya serta apa yang diteliti semoga dapat memberikan manfaat bagi pendidik dan peserta didik.

\section{DAFTAR PUSTAKA}

Agustin, Y., Trisoni, R., \& Putra, A. I. (2018). Penerapan Model Pembelajaran Kooperatif Tipe Think Pair Square terhadap Hasil Belajar Siswa Materi Struktur dan Fungsi Jaringan Tumbuhan pada Kelas VIII SMP Negeri 1 Batusangkar. Keterampilan Abad 21; Strategi Pengembangan Pembelajaran, Penelitian, Matematika dan Sains (pp. 47-58).

Amiluddin, R., \& Sugiman, S. (2016). Pengaruh Problem Posing dan PBL terhadap Prestasi Belajar, dan Motivasi Belajar Mahasiswa Pendidikan Matematika. Jurnal Riset Pendidikan Matematika, 3(1), 100-108.

Anwar, \& Ugi, L. E. (2017). Penerapan Model Pembelajaran Kooperatif Tipe Think Pair Square pada Materi Ruang Dimensi Tiga untuk Meningkatkan Prestasi Belajar Matematika Siswa Kelas X SMA Negeri 1 Baubau. Jurnal Penelitian Pendidikan dan Pengajaran Matematika, 3(1), 1-12.

Azizah, D. (2013). Penerapan Pendekatan Struktural Metode Think Pair Share (TPS) pada Materi Lingkaran untuk Meningkatkan Aktivitas Belajar Matematika Siswa. Delta, 1(2), 188-193.

Deta, U. A., -, S., \& Widha, S. (2013). Pengaruh Metode Inkuiri Terbimbing dan Proyek, Kreativitas, serta Keterampilan Proses Sains terhadap Prestasi Belajar Siswa. Jurnal Pendidikan Fisika Indonesia (Indonesian Journal Of Physics Education), 9(1), 28-34.

Fahrurrozi, \& Mahmudi, A. (2014). Pengaruh PBM dalam Setting Pembelajaran Kooperatif Tipe Stad dan GI Terhadap Prestasi Belajar dan Kecerdasan Emosional Siswa. 
Jurnal Riset Pendidikan Matematika, 1(1), 1-11.

Farhan, M., \& Retnawati, H. (2014). Keefektifan PBL dan IBL ditinjau dari Prestasi Belajar, Kemampuan Representasi Matematis, dan Motivasi Belajar. Jurnal Riset Pendidikan Matematika, 1(2), 227240.

Handhika, J. (2010). Pembelajaran Fisika Melalui Inkuiri Terbimbing dengan Metode Eksperimen dan Demonstrasi ditinjau dari Aktivitas dan Perhatian Mahasiswa. JP2F, 1(April), 9-23.

Januartini, P. D., Agustini, K., \& Sindu, I. G. P. (2016). Studi Komparatif Model Pembelajaran Think Pair Square dan Think Pair Share Terhadap Motivasi dan Hasil Belajar Siswa Mapel TIK Kelas X SMA N 1 Sukasada. Jurnal Pendidikan Teknologi dan Kejuruan, 13(2), 148-160.

Karubaba, S. A. M., Rahman, B., \& Arifin. (2019). Pengaruh Model Pembelajaran Kooperatif Tipe Think Pair Square terhadap Kemampuan Pemahaman Konsep Matematis Siswa. Indomath: Indonesian Mathematics Education, 2(1), 37-44.

Karyawati, N. K., Murda, I. N., \& Widiana, I. W. (2014). Pengaruh Model Pembelajaran Kooperatif Tipe Think Pair Square ( TPS ) Berbantuan Kartu Kerja terhadap Hasil Belajar Matematika. Jurnal Mimbar PGSD Universitas Pendidikan Ganesha, 2(1).

Listyanto, A. D., \& Munadi, S. (2013). Pengaruh Pemanfaatan Internet, Lingkungan dan Motivasi Belajar Terhadap Prestasi Belajar Siswa SMK. Jurnal Pendidikan Vokasi, 3(3), 293-306.

Marlissa, I., \& Widjajanti, D. B. (2015). Pengaruh Strategi React ditinjau dari Gaya Kognitif terhadap
Kemampuan Pemecahan Masalah, Prestasi Belajar dan Apresiasi Siswa terhadap Matematika. Jurnal Riset Pendidikan Matematika, 2(2), 186-196.

Maznah. (2016). Peningkatan Hasil Belajar Matematika melalui Model Pembelajaran Kooperatif Tipe Think Pair Square (TPS) Kelas VI SDN 001 Empat Balai Kecamatan Kuok Kabupaten Kampar. Jurnal Primary, 5(3), 427-441.

Ningtiyas, P., \& Siswaya, H. (2012). Penggunaan Metode Kooperatif Tipe TGT dilengkapi Modul dan LKS ditinjau dari Aktivitas Siswa. Jurnal Penelitian Pembelajaran Fisika, 3(1), 51-58.

Nugraheni, E. A., \& Sugiman. (2013). Pengaruh Pendekatan PMRI terhadap Aktivitas dan Pemahaman Konsep Matematika Siswa SMP. Pythagoras: Jurnal Pendidikan Matematika, 8(1), 101108.

Oktapiani, K. S., Wibawa, I. M. C., \& Garminah, N. N. (2016). Pengaruh Model Pembelajaran TPS Berbantuan Media Permainan Puzzel terhadap Hasil Belajar IPA Siswa Kelas IV. E-Journal PGSD Universitas Pendidikan Ganesha, 4(1), 1-10.

Rusmawati, P. E., Candiasa, I. M., \& Kirna, I. M. (2013). Pengaruh Model Pembelajaran Kooperatif TGT terhadap Prestasi Belajar Matematika ditinjau dari Motivasi Berprestasi Siswa Kelas VIII SMP Negeri 2 Semarapura. E-Journal Program Pascasarjana Universitas Pendidikan Ganesha, 3.

Sanjaya, W. (2002). Strategi Pembelajaran Berorientasi Standard Proses Pendidikan. Bandung: Kencana.

Satriawan, R. (2017). Keefektifan Model Search, Solve, Create, and Share ditinjau dari Prestasi, Penalaran 
Matematis, dan Motivasi Belajar. Jurnal Riset Pendidikan Matematika, 4(1), 87-99.

Siregar, M. (N.D.). Strategi Penerapan Metode Think Pair Square dalam Meningkatkan Kemampuan Melakukan Operasi Hitung Siswa Belajar Matematika, (1).

Siregar, N. C., \& Marsigit. (2015). Pengaruh Pendekatan Discovery yang Menekankan Aspek Analogi terhadap Prestasi Belajar, Kemampuan Penalaran, Kecerdasan Emosional Spiritual. Jurnal Riset Pendidikan Matematika, 2(2), 224-234.

Solfitri, T., \& Heleni, S. (2015). Penerapan Model Pembelajaran Kooperatif Tipe Think Pair Square untuk Meningkatkan Hasil Belajar Matematika Siswa Kelas X3 SMA Negeri 5 Pekanbaru. Al-Khwarizmi, III(1), 33-50.

Sukmawati, S., \& Nasrullah, A. (2017). Penerapan Model Pembelajaran Kooperatif Pendekatan Struktural Think Pair Square untuk Meningkatkan Hasil Belajar Matematika Siswa. JPPM, 10(1),
115-124.

Sumaryati, E., \& Sumarmo, U. (2013). Pendekatan Induktif- Deduktif Disertai Strategi Think-PairSquare-Share untuk Meningkatkan Kemampuan Pemahaman dan Berpikir Kritis serta Disposisi Matematis Siswa SMA. Infinity, 2(1), 26-42.

Tiurma, L., \& Retnawati, H. (2014). Keefektifan Pembelajaran Multimedia Materi Dimensi Tiga ditinjau dari Prestasi dan Minat Belajar Matematika di SMA. Jurnal Kependidikan, 44(2), 175-187.

Wahidin, \& Sugiman. (2014). Pengaruh Pendekatan Pmri terhadap Motivasi Berprestasi, Kemampuan Pemecahan Masalah, dan Prestasi Belajar. Pythagoras, 9(1), 99-109.

Yaqin, M. A., Indriwati, S. E., \& Susilo, H. (2018). Think-Pair-Square Learning: Improving Student's Collaborative Skills and Cognitive Learning Outcome on Animal Diversity Course. JPBI (Jurnal Pendidikan Biologi Indonesia), 4(2), 135-142. 